\title{
Program terytorialny Komitetu Narodowego Polskiego i delegacji polskiej na konferencji pokojowej w Wersalu
}

\section{Piotr Eberhardt}

Podczas pierwszej wojny światowej, a zwłaszcza w jej początkowej fazie, trudno było przewidzieć, jakie mogą być granice polityczne ewentualnie odrodzonego państwa polskiego. Bardziej realnym scenariuszem było powstanie autonomicznej prowincji o szczątkowej samodzielności w ramach zwycięskiej Rosji lub Niemiec. Nie było wiadomo, jakie będą rezultaty wojny i która ze stron konfliktu zwycięży. Dlatego też w społeczeństwie polskim i wśród jego elit pojawiały się różne opinie i opcje ideowe. Zostały one wyrażone przez uformowanie się dwóch orientacji politycznych. Jedna z nich postawiła na państwa centralne, druga zaś sądziła, że lepszym rozwiązaniem będzie militarne wsparcie państw ententy. Zwycięstwo każdej ze stron przynosiło odmienne konsekwencje dotyczące zarówno geopolityki, jak i przyszłości Polski oraz Polaków, w tym powstanie odmiennych układów granicznych. Formułowane postulaty terytorialne musiały być wobec tego zróżnicowane, a spełnienie każdego z nich obciążone było niepewnością. Sądzono, że sprawa ta nabierze aktualności dopiero w momencie zakończenia wojny. $\mathrm{Z}$ tego powodu strona polska musiała być przygotowana na wszelkie ewentualności, by w zależności od powstałej sytuacji zająć realistyczne i umotywowane stanowisko. Dopiero wtedy byłby odpowiedni czas dla skonstruowania uzasadnionych i precyzyjnych postulatów co do zasięgu i rozległości terytorialnej wskrzeszonego państwa polskiego.

Pojawiały się w tym czasie liczne koncepcje indywidualnych badaczy, którzy kreślili granice przyszłej Polski. Warianty te różniły się między sobą znacznie ${ }^{1}$ - od postulatów minimalistycznych po takie, których spełnienie było całkowicie nieprawdopodobne. Zdawano sobie tylko sprawę, że przywrócenie granic politycznych z 1772 r. jest całkowicie nierealne. Nie wynikało to jedynie ze słabości politycznej i militarnej, ale również z pojawienia się aspiracji narodowych wśród Ukraińców, Białorusinów i Litwinów. Odrzucano również powszechnie koncepcje niewielkiej Polski w wąskich granicach etnicznych pod kuratelą Niemiec lub Rosji. Słusznie zakładano, że Polska ograniczona do tak niewielkiego obszaru byłaby niezdolna do samodzielnej egzystencji i skazana na stopniowe unicestwienie.

Wychodząc z tego założenia, przy konstruowaniu przyszłych granic odrodzonego państwa polskiego wykorzystywano łącznie uzasadnienia historyczne, etniczne i strategiczne. Liczono się z możliwością odwetu, względnie rewanżyzmu niemieckiego lub rosyjskiego, które stanowiłyby zawsze realne zagrożenie dla narodu polskiego.

Uwarunkowania polityczne na arenie międzynarodowej były niezmiernie złożone i obarczone dużą niepewnością co do przyszłości. Wszystko to sprawiało, że poglądy Polaków były niejednolite i trudno było doprowadzić do spójnego stanowiska w kwestii terytorialnej. Niemniej problematyka ta stała się obiektem zainteresowania wszystkich polskich ugrupowań politycznych w kraju i na emigracji.

W miarę przeciągania się wojny, wydarzeń w Rosji oraz niepowodzeń militarnych państw centralnych coraz większą rolę polityczną zaczęła odgrywać grupa polskich działaczy przebywających na Zachodzie i związanych politycznie z państwami ententy. Niekwestionowanym ich przywódcą był Roman Dmowski, który w Lozannie, a następnie w Paryżu zaczął tworzyć namiastkę przyszłego rządu polskiego. Środowisko to było przekonane, że opcja zachodnia

\footnotetext{
1 Opracowano liczne projekty autorskie. Granice przyszłej Polski były wykreślone na mapach m.in. przez: Czesława Jankowskiego, Włodzimierza Wakara, Eugeniusza Romera, Wiktora Skargę-Dobrowolskiego, Adama Szelągowskiego, Józefa Jaskólskiego. Zostały one przedstawione i skomentowane w książce P. Eberhardt, Polska i jej granice. Z historii polskiej geografii politycznej, Lublin 2014.
} 
jest dla Polski najbardziej korzystna i ostatecznie przyniesie możliwość ukonstytuowania się niepodległego państwa polskiego po klęsce państw centralnych. Grupa czołowych działaczy związanych z Narodową Demokracją zebrała się w 1916 r. w Lozannie, aby ustalić program działań zmierzających do odbudowy niepodległego państwa polskiego. Inicjatorem tych działań był, jak wspomniano, Roman Dmowski, który po opuszczeniu Petersburga w grudniu 1915 r. przybył do Lozanny, aby zintegrować środowisko swoich politycznych zwolenników. Odwiedził również Paryż i Londyn, a nawet Watykan, gdzie złożył wizytę papieżowi Benedyktowi XIV². Przebywając w Londynie, odbył rozmowę z ministrem spraw zagranicznych Wielkiej Brytanii Arthurem Balfourem i starał się przekonać go o celowości odrodzenia niepodległego państwa polskiego. Gdy Dmowski podróżował po zachodniej Europie, formalnie nadal był obywatelem rosyjskim. Ponieważ Rosja była sojusznikiem Anglii i Francji, musiał zachować z nią poprawne stosunki. W celu powierzchownego wykazania lojalności w kwietniu 1916 r. przygotował dla ambasadora rosyjskiego w Paryżu Aleksandra Izwolskiego memoriał, w którym poruszał sprawę zjednoczenia ziem polskich $^{3}$. Nie podnosił w tym dokumencie kwestii granicznych, ale wyraził swoją opinię o konieczności zlikwidowania kordonów granicznych państw zaborczych przecinających ziemie polskie. Podobną rozmowę przeprowadził $\mathrm{z}$ ambasadorem rosyjskim $\mathrm{w}$ Londynie hr. Aleksandrem Benckendorffem.

Następny przyjazd Romana Dmowskiego do Lozanny przyczynił się do ogłoszenia 11 listopada 1916 r. tzw. deklaracji lozańskiej. Ten kolejny memoriał polityczny powstał bezpośrednio po znanym akcie z dnia 5 listopada 1916 r., w którym państwa centralne oficjalnie zadekla-

\footnotetext{
2 Wizyta u papieża miała charakter kurtuazyjny. Ciekawą rozmowę przeprowadził Dmowski w Watykanie z kard. Pietrem Gasparim oraz jego sekretarzem Eugeniem Paccelim, późniejszym papieżem Piusem XII, którzy nakłaniali go do sojuszu z katolicką Austrią. J. Zamoyski, Powrót na mape Polski. Komitet Narodowy w Paryżu 1914-1919, Londyn 1984, s. 17; R. Dmowski, Polityka polska i odbudowanie państwa, w: tenże, Wybór pism, t. 1, Poznań 2014, s. 334.

3 Memoriał ten został zamieszczony w zbiorze tekstów przywódcy obozu
} narodowego: R. Dmowski, Polityka polska (2014), s. 611-622. rowały możliwość utworzenia państwa polskiego po zakończeniu zwycięskiej dla nich wojny. Pomimo że nie określono jego granic oraz stopnia niezależności, stanowiło to ważne wydarzenie, wobec którego zarówno alianci zachodni, jak i Rosja nie mogli zachować obojętności.

Deklaracja lozańska była punktem inicjującym utworzenie oficjalnej reprezentacji przedstawicielstwa narodu polskiego ${ }^{4}$. Bezpośrednio po tym nie tylko formalnym akcie powstał Komitet w składzie: Roman Dmowski, Erazm Piltz, Marian Seyda, Kazimierz Morawski, Jan Rozwadowski i Jan Żółtowski. Następnie zostali do niego powołani kolejni działacze reprezentujący Narodową Demokracje, m.in.: Maurycy Zamoyski, Konstanty Skirmunt ${ }^{5}$, Władysław Sobański, Ignacy Paderewski. Z inicjatywy tych działaczy - deklarujących swoją lojalność wobec państw ententy i zamierzających przy ich pomocy odtworzyć niepodległe państwo polskie - zorganizowano tzw. zjazd lozański. Odbył się on między 26 stycznia a 2 lutego 1917 r., a najważniejszym jego osiągnięciem było zainicjowanie działania Komitetu Narodowego Polskiego (KNP) ${ }^{6}$. Formalne powołanie organizacji miało miejsce 15 sierpnia $1917 \mathrm{r}$. na kolejnym zjeździe działaczy związanych ideowo z programem Narodowej Demokracji. $\mathrm{Na}$ oficjalną siedzibę Komitetu wybrano Paryż, a jego prezesem został Roman Dmowski. Zadaniami KNP były obrona interesów Polski i jej reprezentacja na forum międzynarodowym, w tym głównie przed aliantami zachodnimi, następnie zaś utworzenie armii polskiej

\footnotetext{
${ }^{4}$ W deklaracji lozańskiej stwierdzono: „Naród polski jest jeden i niepodzielny. Jego dążenie do własnego państwa obejmuje wszystkie trzy części Polski i bez zjednoczenia ich nie może być zaspokojone". R. Dmowski, Polityka polska (2014), s. 625.

5 Autor interesujących wspomnień, w których przedstawiono wiele ciekawych spostrzeżeń o ludziach działających w KNP. K. Skirmunt, Moje wspomnienia 1866-1945, red. E. Orlof, A. Pasternak, Rzeszów 1997.

6 Literatura na temat Komitetu Narodowego Polskiego i jego wkładu w odbudowę niepodległości Polski jest dość obszerna: M. Leczyk, Komitet Narodowy Polski a Ententa i Stany Zjednoczone, Warszawa 1966; J. Pajewski, Wokót sprawy polskiej. Paryż - Lozanna - Londyn 1914-1918, Poznań 1970; R. Wapiński, Komitet Narodowy Polski i jego wkład w odbudowę niepodległości Polski (1917-1919), w: Powrót Polski na mapę Europy, red. C. Bloch, Z. Zieliński, Lublin 1995. Z tego powodu nie zachodzi potrzeba omawiania tej istotnej kwestii.
} 
we Francji oraz opieka nad Polakami przebywającymi na obczyźnie. W ramach KNP funkcjonowała Polska Centralna Agencja (Polish Central Agency). Pod jej auspicjami w 2. poł. 1917 r. opracowano i opublikowano w formie kartograficznej projekt graniczny przyszłego państwa polskiego. Był on przeznaczony dla odbiorcy zagranicznego, gdyż mapa miała tytuł anglojęzyczny: Territories of Poland under the Domination and Occupation of Austro-Germany (mapa 1).

Zamieszczona w niniejszym tekście mapa jest dokumentem oryginalnym, mało znanym i dlatego godnym przypomnienia. W 1917 r. nie odegrała znaczniejszej roli politycznej, gdyż szybko się zdezaktualizowała, a do tego od początku miała wydźwięk propagandowy. Niemniej jednak jest interesującą ilustracją karto- graficzną, a w treści dotyczącej granic przyszłej Polski stanowi propozycję zaskakującą, a nawet szokującą. Nie zmienia to faktu, że w pewnym stopniu była odzwierciedleniem poglądów na przyszłość Polski, z którymi identyfikowali się czołowi polscy politycy związani z KNP. Poprzedziła ona propozycję graniczną Romana Dmowskiego z 1919 r., która to była już oficjalnym dokumentem polskiej delegacji rządowej zaprezentowanym na konferencji paryskiej w Wersalu.

Granice postulowanego państwa polskiego (nakreślone na mapie nr 1) zawierały Królestwo Polskie, Wielkopolskę, Pomorze Gdańskie, Prusy Wschodnie, etniczną Litwę z Wilnem, austriacką Galicję, Polesie, niewielką część Wołynia oraz w przybliżeniu ówczesną gubernię grodzieńską.

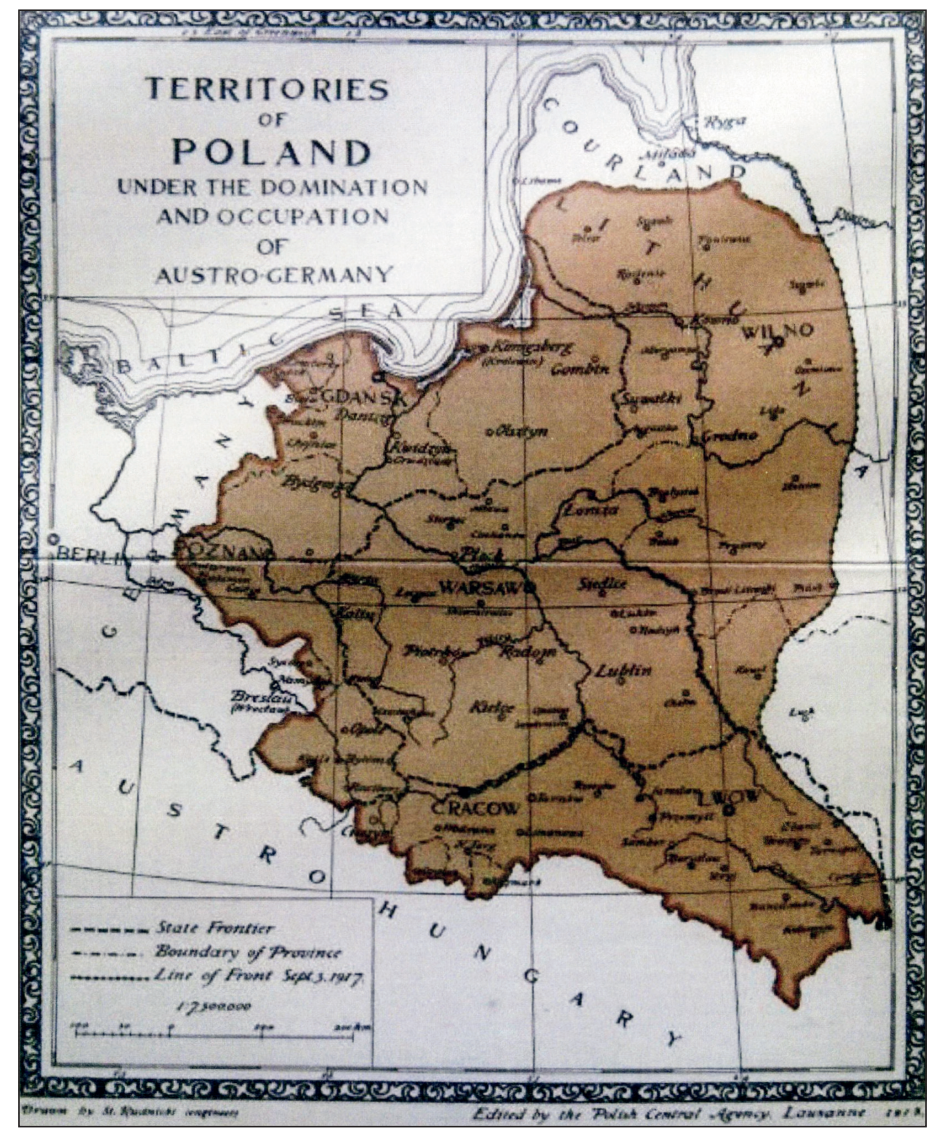

Mapa 1. „Territories of Poland under the Domination and Occupation of Austro-Germany”, Polish Central Agency, Lozanna 1917 
Granica wschodnia postulowanej Polski była ograniczona aktualną linią frontu niemiecko-rosyjskiego według stanu z 3 września 1917 r., zaś zachodnia, odgraniczająca Polskę od Niemiec, była zmodyfikowaną na korzyść Polski granicą I Rzeczypospolitej z 1772 r. W ramach tej modyfikacji dołączono do Polski pas przygraniczny, obejmujący wybrzeże aż po Słupsk oraz ziemie bytowską, złotowską i wałecką. Nieznacznie poszerzono też Wielkopolskę. Poważniejsze zmiany proponowano natomiast w południowej części pogranicza polsko-niemieckiego. W skład Polski zamierzano włączyć Górny Śląsk z Opolszczyzną. Ta mało znana historykom i geografom mapa nie była rozpowszechniana i została zapomniana. Sądzić można, że przedstawiona wizja graniczna od początku była mało realna. Trudno sobie wyobrazić w ówczesnych uwarunkowaniach politycznych całkowitą likwidację Prus Wschodnich oraz pełną inkorporację etnicznej Litwy do Polski lub też określenie wschodniej granicy państwa polskiego na dość przypadkowej linii zmieniającego się frontu niemiecko-rosyjskiego.

Wydarzenia związane z rewolucją bolszewicką w Rosji zmieniły sytuację militarną, a zawarty w Brześciu pokój przesunął linię frontu daleko na wschód ${ }^{7}$. Zaprezentowane ujęcie kartograficzne - pomimo jego utopijności - świadczyło o właściwej intuicji autorów. Oczekiwali oni totalnej klęski państw centralnych i możliwości wyznaczenia korzystnej dla Polski granicy polsko-niemieckiej. Trudno określić, jaki udział w tym oryginalnym dziele miał sam Roman Dmowski, który nie wspomina o nim w swoich relacjach i tekstach autorskich. Niemniej skrajnie antyniemiecka wymowa ideowa tej mapy była zgodna z jego poglądami ${ }^{8}$.

Działalność polityczna KNP nabierała coraz większego znaczenia na arenie międzynarodo-

7 Pokój niemiecko-bolszewicki w Brześciu uznał m.in. przynależność Chełmszczyzny do tzw. państwa ukraińskiego.

8 Na marginesie mapy podane jest nazwisko wykonawcy: Stefana Rudnickiego.

9 Pierwszym państwem, które uznało Komitet Narodowy Polski, była Francja (20 września 1917 r.), następnie uczynity to Wielka Brytania (15 października 1917 r.) oraz Włochy (30 października 1917 r.) i wreszcie Stany Zjednoczone (1 grudnia 1917 r.) wej. Wynikało to z uznania go przez mocarstwa zachodnie jako jedynego przedstawiciela narodu polskiego', co wzmacniało pozycję Komitetu i sprzyjało umiędzynarodowieniu sprawy polskiej. Dopóki jednak trwała wojna, kwestie politycznych rozgraniczeń na ziemiach polskich nie były obiektem zainteresowania sojuszników zachodnich. Mimo to strona polska, a zwłaszcza osobiście Roman Dmowski, konsekwentnie stawiała tę sprawę na forum międzynarodowym. Dokumentem, który dotyczył przyszłego terytorium państwa polskiego, był memoriał w sprawie „uznania niepodległości Polski przez mocarstwa sprzymierzone wespół z Rosją" złożony przez Dmowskiego sekretarzowi stanu Wielkiej Brytanii Jamesowi Balfourowi w marcu $1917 \mathrm{r}^{10}$ Określono w nim najbardziej pożądane terytorium, które powinno stanowić integralną część Polski. Obejmowało ono:

- Polskę austriacką, tzn. całą Galicję i połowę Śląska Cieszyńskiego;

- Polskę rosyjską, tzn. Królestwo Polskie oraz gubernie kowieńską, wileńską, grodzieńską oraz część mińskiej i wołyńskiej;

- Polskę niemiecką, tzn. Poznańskie, Prusy Zachodnie z Gdańskiem, Górny Śląsk i południowy pas Prus Wschodnich ${ }^{11}$.

Uzasadnienie postulatów terytorialnych zawarte zostało w opracowaniu pt. Problem of Central and Eastern Europe przygotowanym przez Romana Dmowskiego w lipcu 1917 r., a następnie przekazanym aliantom zachodnim. W tym obszernym dokumencie przedstawiającym problematykę geopolityczną Europy Środkowo-Wschodniej i konieczność jej przebudowy terytorialnej Roman Dmowski określił dezyderaty polskie. Terytorium państwa polskiego zbliżone byłoby wielkością do Francji lub Niemiec. Będąc sprzymierzone z mocarstwami zachodnimi, stanowiłoby istotny czynnik równowagi europej-

\footnotetext{
10 W memoriale tym Roman Dmowski uzasadnił, że „deklaracja o niepodległości Polski nie będzie żadną miarą aktem przeciwrosyjskim". R. Dmowski, Polityka polska i odbudowanie państwa, t. 2, Hanower 1947, s. 78.

11 Według Romana Dmowskiego sformułowany program terytorialny zapewniał „utrzymanie równowagi europejskiej”, bowiem jedynie „duże i silne” państwo polskie może być niezawisłe od Niemiec. R. Dmowski, Polityka polska (1947), t. 2, s. 79.
} 
skiej i barierę przed potencjalną ekspansją Niemiec na wschód. W dokumencie tym Dmowski nie wnika w sposób szczegółowy w kwestie graniczne i nie zamieszcza ich na mapie, ale strona tekstowa pozwala określić przyblizzony zasięg terytorialny przyszłej odrodzonej Polski ${ }^{12}$.

Podobną wymowę polityczną i geograficzną ma kolejny memoriał, złożony przez Dmowskiego prezydentowi Stanów Zjednoczonych Thomasowi W. Wilsonowi w dniu 8 października 1918 r. Przedstawiono w nim z odpowiednim komentarzem roszczenia terytorialne Polski wobec Niemiec, Rosji i Austrii ${ }^{13}$.

Wyłączenie Rosji z wojny oraz klęska militarna Niemiec i Austro-Węgier dały możliwość bardziej aktywnego działania przedstawicieli narodu polskiego Zasadniczym problemem była kwestia ustalenia granic Polski. Było już wiadomo, że przypieczętowane na kongresie wiedeńskim granice trzech państw zaborczych rozdzielające polskie ziemie przestały istnieć i pojawiła się konieczność ustalenia nowych granic Polski, w tym polsko-niemieckiej, która miała zostać określona przez państwa zachodnie na zbliżającej się konferencji pokojowej. Przebieg przyszłej granicy wschodniej Polski był uzależniony od nieuniknionej konfrontacji z bolszewicką Rosją. Wpływ mocarstw zachodnich był tu już dość ograniczony, niemniej starały się one pełnić rolę rozjemcy, a częściowo również sojusznika Polski.

W momencie odrodzenia niepodległego państwa rzecznikiem narodu polskiego wobec mocarstw zachodnich przestał być Komitet Narodowy Polski, który stopniowo zaprzestał dzia-

12 Dokument jest bardzo obszerny, gdyż dotyczy koncepcji przebudowy terytorialnej w zasadzie wszystkich państw położonych miedzy Bałtykiem, Morzem Czarnym i Adriatykiem. R. Dmowski, Polityka polska (1947), t. 2, s. 83-142.

13 Trzy kolejno przypomniane dokumenty zawarte są również w zbiorze tekstów autorstwa Romana Dmowskiego: R. Dmowski, Polityka polska (2014), s. 625-628, 637-707, 720-741.

14 Kwestia ta została opisana i skomentowana m.in. w monumentalnej książce poświęconej dziejom Polski w XX w.: W. Pobóg-Malinowski, Najnowsza historia polityczna Polski, t. 2, słowo wstępne B. Świderski, Londyn 1953, s. 218-253.

15 Pełna dokumentacja dotycząca działalności polskich ekspertów na konferencji pokojowej w Wersalu zawarta jest w opracowaniu Ekspertyzy i materiały delegacji polskiej na konferencję wersalską 1919, red. M. Przyłuska-Brzostek, Warszawa 2009. W trakcie konferencji łalności na arenie międzynarodowej, przekazując uprawnienia poszczególnym ministrom usytuowanym w Warszawie, a przede wszystkim Ministerstwu Spraw Zagranicznych. Decyzja o likwidacji KNP zapadła 15 kwietnia 1919 r., ale do tego czasu - pomimo poważnych kontrowersji, nie tylko kompetencyjnych - starał się on wspierać działania władz warszawskich ${ }^{14}$.

Jedną z najważniejszych kwestii, które stanęły przed nowo powstałym państwem polskim, było przygotowanie odpowiednio umotywowanego stanowiska, które należało przyjąć na zbliżającej się konferencji pokojowej w Paryżu. Miała ona zadecydować o nowym porządku geopolitycznym w Europie, w tym określić granice odrodzonej Rzeczypospolitej Polskiej. Wymagało to ustalenia składu polskiej delegacji, która została oficjalnie zaproszona. Na przewodniczącego wybrano Romana Dmowskiego, osobę najbardziej kompetentną i najlepiej przygotowaną do tej odpowiedzialnej i trudnej roli. Znaleźli się w niej również eksperci, m.in. Eugeniusz Romer ${ }^{15}$.

Aby zaprezentować polskie dezyderaty terytorialne, Roman Dmowski wystosował m.in. dwie noty, w których wyłożył argumenty przemawiające za wytyczeniem granic politycznych gwarantujących odpowiednie zapewnienie interesów i bezpieczeństwa państwa polskiego. Pierwsza z nich dotyczyła polskiej granicy zachodniej i została przekazana w dniu 28 lutego 1919 r. przewodniczącemu Komisji Terytorialnej Julesowi Cambonowi. Druga - z dnia 3 marca 1919 r. - skierowana była do tego samego adresata i przedstawiała oczekiwania w sprawie przebiegu granicy wschodniej ${ }^{16}$. Stanowisko

Eugeniusz Romer prowadzit dokładne notatki, które następnie zostały poddane naukowej weryfikacji i opublikowane: E. Romer, $P$ amiętnik paryski (1918-1919), Kraków 1989.

16 We wszystkich opracowaniach dotyczących przebiegu i wyników konferencji pokojowej w Wersalu są one odnotowane i omówione (np.: S. Kozicki, Sprawa granic Polski na konferencji pokojowej w Paryżu 1919 r., Warszawa 1921; K. Kumaniecki, Odbudowa państwowości polskiej. Najważniejsze dokumenty 1912-1924, Warszawa-Kraków 1924; W. Pobóg-Malinowski, Najnowsza historia; T. Piszczkowski, Odbudowanie Polski 1914-1919, Londyn 1969; J. Zamoyski, Powrót na mapę; Powrót Polski na mapę Europy, red. C. Bloch, Z. Zieliński, Lublin 1995). W pełnej objętości zawarte są w opracowaniach Dmowskiego: R. Dmowski, Polityka polska (1947), t. 2, s. 161-168; R. Dmowski, Polityka polska (2014), s. 742-752). 


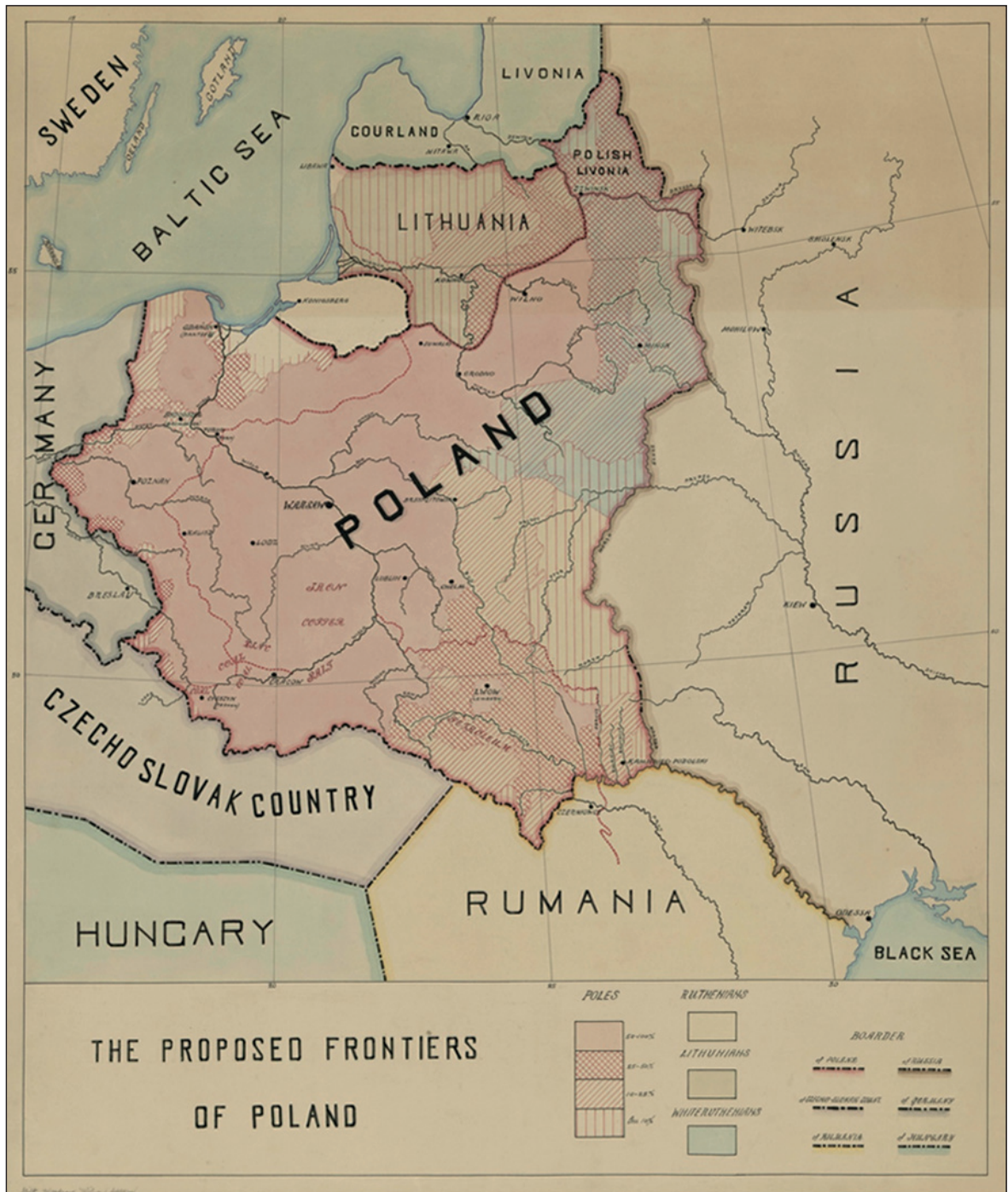

Mapa 2. "The Proposed Frontiers of Poland", Paris 1919 (załącznik do stanowiska delegacji polskiej na konferencji pokojowej $w$ Wersalu)

polskie zostało zaprezentowane $\mathrm{w}$ trakcie plenarnych obrad konferencji wersalskiej. Podczas kilkugodzinnej przemowy wygłoszonej na przemian w językach francuskim i angielskim Roman Dmowski przedstawił żądania terytorialne Polski.

Równocześnie polska delegacja zaprezentowała uczestnikom konferencji specjalnie przygotowaną mapę (mapa 2$)^{17}$. Na górnym marginesie znajdował się jej tytuł w języku angielskim: The Proposed Frontiers of Poland. Nie podano au- tora tego dzieła kartograficznego, gdyż stanowiło ono jedynie załącznik do oficjalnego stanowiska delegacji. $\mathrm{Na}$ mapie przedstawiono terytorium i granice postulowanego państwa polskiego. W składzie Polski obejmującej ziemie trzech zaborów znalazły się dwie prowincje oddzielone

17 Pierwotnie mapa ta była załącznikiem do memoriału Romana Dmowskiego złożonego prezydentowi Wilsonowi dnia 8 października $1918 \mathrm{r}$. Następnie wielokrotnie wykorzystywała ją polska delegacja podczas obrad w Wersalu.

\section{I32 Studia Geohistorica • Nr 03. 2015}


wewnętrzną granicą, a mianowicie Litwa oraz Inflanty Polskie (Polish Livonia). Autorzy mapy - zdając sobie sprawę, że przy ustalaniu granic decydujące mają być kwestie etniczne - ukazali na niej rozmieszczenie ludności narodowości polskiej. Kolorem pomarańczowym wyodrębniono obszary, na których stanowiła bezwzględną większość. Następnie, wykorzystując szraf jako wyznacznik graficzny, zaznaczono obszary o mniejszym udziale ludności polskiej w ogólnym zaludnieniu: $25-50 \%, 10-25 \%$ oraz poniżej $10 \%$. Przedstawiona mapa była w trakcie konferencji kilkakrotnie modyfikowana. Przyczyną były zmiany w sytuacji politycznej oraz względy taktyczne. Nie miało to dużego znaczenia merytorycznego, gdyż delegacja polska, broniąc swoich dezyderatów terytorialnych, zajmowała stanowisko niezmienne i pryncypialne.

Postulaty nawiązujące do rozprzestrzenienia ludności polskiej były maksymalistyczne i zawierały dużo manipulacji statystycznej i kartograficznej. W granicach potencjalnej Polski znalazły się rozległe obszary, na których udział ludności polskiej był znikomy. Dla przekonania przedstawicieli państw ententy, że zaproponowany układ graniczny jest uzasadniony i sprawiedliwy, wykorzystywano dodatkowo argumenty strategiczne, historyczne i ekonomiczne $^{18}$.

Wspomniano już, że w trakcie obrad wersalskich zaprezentowana mapa była kilkakrotnie weryfikowana. Modyfikacje te były spowodowane zmianami w sytuacji politycznej, a dotyczyły głównie wschodniego pogranicza. Dla ukazania pewnej ewolucji w poglądach delegacji polskiej, w tym Romana Dmowskiego, w niniejszym artykule zamieszczono kolejną mapę (mapa 3).

W 1921 r., bezpośrednio po zakończeniu konferencji pokojowej w Wersalu, zaprezentowana została skorygowana wersja oryginalnej

\footnotetext{
18 Przebieg obrad konferencji pokojowej w Wersalu dotyczący wyznaczenia granicy zachodniej państwa polskiego przedstawiono m.in. w opracowaniach: Z. Wroniak, Sprawa polskiej granicy zachodniej w latach 1918-1919, Poznań 1963; M. Baumgart, Wielka Brytania a odbudowa Polski 1914-1923, Szczecin 1990; H. Batowski, Zachód wobec granic Polski 1920-1940: niektóre fakty mniej znane, Łódź 1995
}

mapy, którą wykorzystywała polska delegacja. Opracowana została przez Eugeniusza Romera i zamieszczono ją w atlasie geograficznym przygotowanym przez tego wybitnego polskiego geografa $^{19}$. Zarówno przy tytule, jak i przy legendzie wspomnianej mapy jako autora wskazano Komitet Narodowy Polski. Nie była to zbyt ścisła informacja, gdyż mapa była już firmowana przez przebywającą w Wersalu delegację polską, a powszechnie wskazywano na jej faktycznego projektodawcę, czyli Romana Dmowskiego. W jej treści oraz legendzie zawarto dodatkowe informacje, które były prezentowane w Wersalu. Ukazano w niej rewindykacje polskie w ujęciu wariantowym. Początkowo zakładano możliwość włączenia do Polski całej etnicznej Litwy, następnie - zdając sobie sprawę z aspiracji litewskich - pominięto to terytorium (na mapie obszar ten zakreślono szrafem), ale samo Wilno z najbliższym zapleczem znalazło się w składzie Polski. Postulowany obszar przyszłego państwa polskiego pokryto kolorem czerwonym. Roszczenia Polaków ujęto w dwóch wariantach - ze stycznia 1919 i marca 1919 r. W drugim z nich do terytorium Rzeczypospolitej włączono obszar położony daleko na wschodzie, na pograniczu białorusko-ukraińskim, po obu stronach Prypeci (odgraniczono je na mapie linią białą). Podane różnice między tymi dwoma ujęciami kartograficznymi były nieznaczne, gdyż zasięg geograficzny i konfiguracja granic przyszłej Polski w obu wariantach były w zasadzie do siebie zbliżone.

Postulowane terytorium nowej Rzeczypospolitej obejmowało ziemie należące od stu lat do imperiów niemieckiego, rosyjskiego i austriackiego. Proponowano, aby z ziem państwa niemieckiego do przyszłej Polski przyłączyć całą Wielkopolskę, Pomorze Gdańskie z Toruniem, Bydgoszczą, Gdańskiem i Elblągiem, Powiśle, Warmię, Mazury, Górny Śląsk z prawie całą Opolszczyzną oraz niewielkie skrawki Dolnego Śląska. Z zaboru rosyjskiego włączono Królestwo Polskie bez północnej części ziemi suwalskiej oraz gubernie wileńską, grodzieńską,

\footnotetext{
${ }^{19}$ Atlas ten został wydany pt. Geograficzno-statystyczny atlas Polski
} i jest jednym z najciekawszych polskich dzieł kartograficznych. 


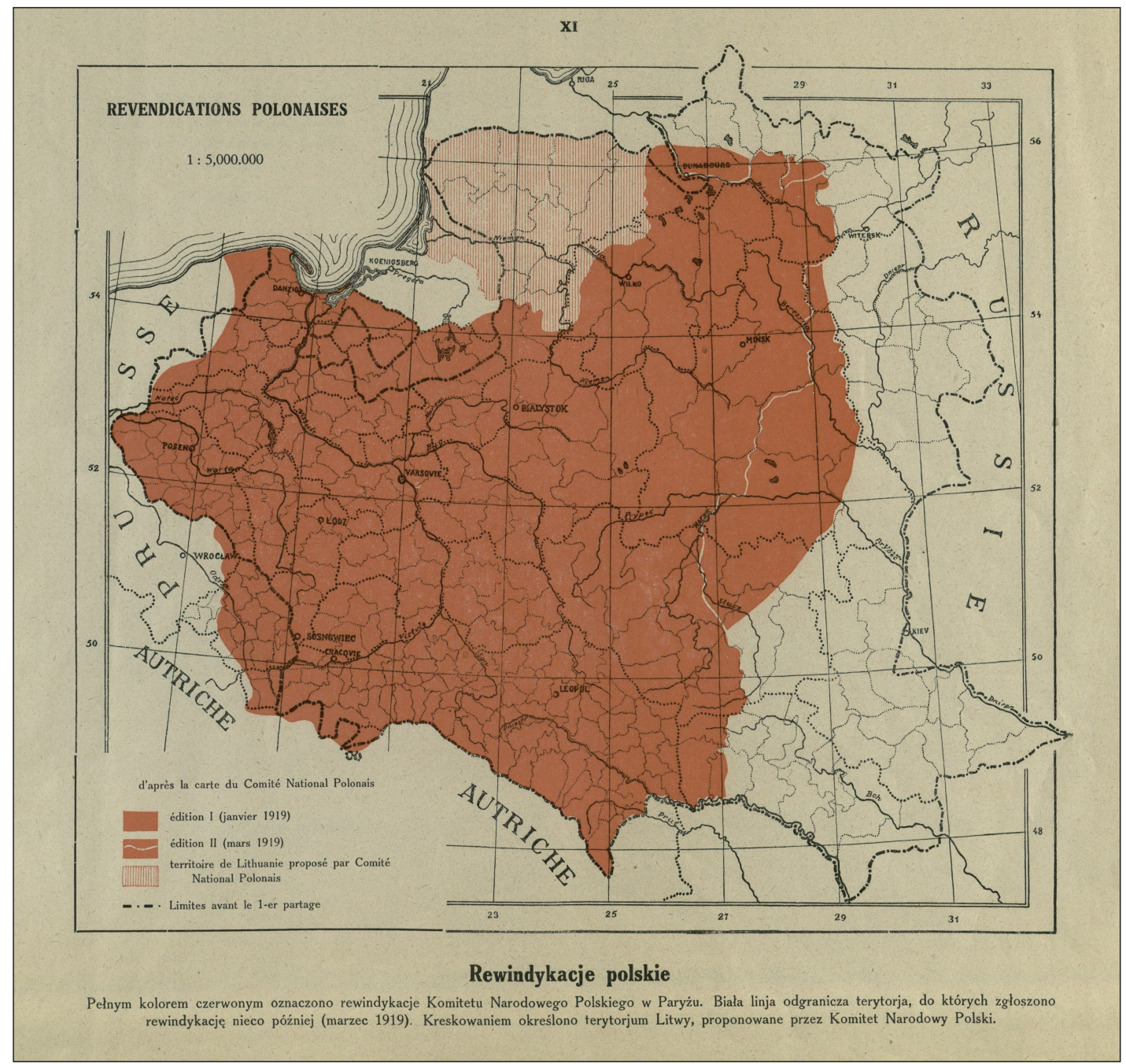

Mapa 3. „Revendications Polonaises”, w: E. Romer, „Polski Atlas Kongresowy”, Książnica Polska Towarzystwa Nauczycieli Szkół Wyższych, Lwów-Warszawa 1921

mińską, zachodnią część witebskiej, wołyńską oraz niewielką część zachodniej guberni podolskiej. Z obszaru należącego do Austro-Węgier postulowano całą Galicję, dużą część Śląska Cieszyńskiego oraz północną część Spiszu i Orawy.

Przy wykreślaniu granicy polsko-niemieckiej punktem wyjścia dla Romana Dmowskiego było historyczne rozgraniczenie z 1772 r., zmodyfikowane na korzyść Polski. Według tego projektu Rzeczpospolita powinna uzyskać szerszy dostęp do Bałtyku, m.in. cały powiat lęborski.
Granica polsko-niemiecka była linią przeciągniętą od Bałtyku do zachodniego krańca Karpat, wyginającą się w kierunku zachodnim w środkowym przebiegu, tak aby w zasadzie cała Wielkopolska znalazła się w granicach Polski. Granica przebiegała bezpośrednio w pobliżu następujących miast, które miały być po stronie Polski: Lębork, Bytów, Złotów, Chojnice, Piła, Drezdenko, Babimost, Kargowa, Wschowa, Milicz, Kluczbork, Opole, Krapkowice, Koźle, Baborów, Racibórz i na zachód od tego miasta dochodzić miała do granicy z kształtującą się

\section{I34 Studia Geohistorica • Nr 03. 2015}


Czechosłowacją. Na północy projektodawca zakładał pozostawienie okrojonych ze wszystkich stron Prus Wschodnich, stanowiących niewielką eksklawę. $\mathrm{Na}$ tym odcinku Roman Dmowski przesuwał granicę polsko-niemiecką na północ. Miała ona przebiegać wzdłuż północno-wschodnich granic historycznej polskiej Warmii, a następnie przybierała układ równoleżnikowy i wytyczona była od warmińskiego Reszla do granicy guberni suwalskiej, przechodząc w pobliżu mazurskiego Rastenborku (Kętrzyna), Żądzborka (Mrągowa), Leca (Giżycka) i na północ od Margrabowej (Olecka), tak aby po stronie polskiej pozostawić polskojęzyczną ludność mazurską.

Najbardziej znana w literaturze przedmiotu jest postulowana granica wschodnia Polski, która od swego kreatora przyjęła nazwę linii Dmowskiego. Przebieg tego rozgraniczenia od Kurlandii do Rumunii został zamieszczony w nocie delegacji polskiej z dnia 3 marca 1919 r. ${ }^{20}$ Można go więc przytoczyć w wersji oryginalnej: „Granica idzie brzegiem (limite) powiatu Iłłuksztańskiego do rzeki Dźwiny i przechodzi na jej prawy brzeg (gubernia Witebska), ażeby postępować ku wschodowi równolegle do rzeki, a w odległości około 30 kilometrów do granic powiatu Drysieńskiego, włączając tenże wraz z powiatem Połockim. Dalej przechodzi ona na północno-zachód od Horodka, powraca na lewy brzeg Dźwiny około 30 kilometrów na zachód od Witebska i idzie ku południowi, przechodząc na zachód od Sienna do punktu, w którym spotyka granicę pomiędzy gubernią Mińską i Mohylowską, postępując tą linją graniczną ku południowi aż do Berezyny w miejscu, gdzie ona dotyka granicy północnej powiatu Rzeczyckiego, następnie przekraczając Berezynę, idzie w kierunku południowo-zachodnim do Prypeci na wschód od Mozyrza. Stamtąd, przekraczając Prypeć, granica idzie linją podziału pomiędzy powiatami Mozyrskim a Rzeczyckim, poczem, postępując ciągle w kierunku południowo-zachodnim, przechodzi na zachód od miast

20 Pełny tekst noty zawarty jest m.in. w zbiorze prac przewodniczącego polskiej delegacji: R. Dmowski, Polityka polska (1947), t. 2, s. 166167.
Owrucza i Zwiahla na Wołyniu i dochodzi do punktu, gdzie spotykają się granice powiatów Zasławskiego, Ostrogskiego i Zwiahelskiego. Następnie kierując się na południe, linja graniczna postępuje granicą wschodnią powiatów Zasławskiego i Staro-Konstantynowskiego aż do punktu, gdzie spotyka granice powiatów Latyczowskiego i Płoskirowskiego na Podolu; stamtąd, ciągle w kierunku południowym, dosięga ona koło Zińkowa rzekę Uszycę i idzie jej biegiem do Dniestru, który stanowi w tem miejscu południową granicę pomiędzy Polską a Rumunją"21.

Przedstawienie tej propozycji granicznej przez polską delegację miało charakter symboliczny. Bez takiej czy innej akceptacji strony rosyjskiej (bolszewickiej) nie miało to większego znaczenia politycznego. Mocarstwa zachodnie nie były władne podejmować w tej kwestii jakichkolwiek decyzji, obligując stronę rosyjską. Wiadomo było, że wszystko ukształtuje się ostatecznie po konflikcie militarnym i od niego będzie zależata konfiguracja wschodniej granicy Polski. Nie istnieją tu więc analogie do granicy zachodniej, która w zasadzie była wytyczona przez mocarstwa zachodnie ${ }^{22}$.

Mniej ważne, ale niezmiernie skomplikowane było ustalenie granic polsko-litewskiej i polsko-czechosłowackiej. Odnośnie do pierwszej Roman Dmowski projektował rozgraniczenie na zachód od Wilna i pozostawienie tego miasta na terytorium Polski. Przy podziale Śląska Cieszyńskiego Polacy wykorzystywali argumenty etniczne, zaś Czesi historyczne. Delegacja polska wysuwała żądania włączenia do swego państwa wszystkich obszarów, na których przeważała ludność narodowości polskiej. Według analizowanej mapy takie miejscowości, jak Bogumin, Karwina, Orłowa, Hawierzów, Trzyniec czy Jabłonków powinny być przyłączone do Polski. Ponadto Roman Dmowski proponował zmodyfikować dawną granicę między Galicją a Górnymi Węgrami na odcinku orawskim i spiskim.

\footnotetext{
21 Podany cytat znajduje się w niedawno wydanym wyborze pism Romana Dmowskiego: R. Dmowski, Polityka polska (2014), t. 2, s. 751-752.

22 Na pewną ich modyfikację wpłynęły działania strony polskiej, np. po-
} wstanie wielkopolskie i trzy powstania śląskie. 
Postulował włączenie do Polski tych gmin, w których ludność miejscowa posługiwała się dialektami języka polskiego, a nie słowackiego ${ }^{23}$.

Dwie załączone do tekstu i poddane analizie mapy, których inspiratorem był bezpośrednio Roman Dmowski, w swojej wymowie ideowej i terytorialnej są klarowne. Odznaczały się one swoistym maksymalizmem, ale dla ówczesnego społeczeństwa polskiego - w którego świadomości ciągle istniała Rzeczpospolita w granicach z 1772 r. - propozycja była umiarkowana i sprawiedliwa. Urzeczywistnienie jej wymagało wyjątkowo sprzyjających uwarunkowań politycznych, a pełne zrekonstruowanie było mało prawdopodobne. Tak też się stało w rzeczywistości. Nie udało się zrealizować postulatów w odniesieniu do granicy zachodniej. W rezultacie antypolskiego stanowiska brytyjskiego ministra spraw zagranicznych Lloyda George'a Polska nie uzyskała Gdańska, a również na pograniczu zachodnim nastąpiły weryfikacje na korzyść Niemiec. Decyzje o plebiscytach przyniosły utratę Mazur (z wyjątkiem powiatu działdowskiego ${ }^{24}$, Warmii, dużej części Powiśla, a przede wszystkim - pomimo powstań - zachodniej części Górnego Śląska (w tym Opolszczyzny). Podobnie niekorzystne dla Polski decyzje mocarstw zachodnich dotyczyły Śląska Cieszyńskiego i pogranicza polsko-słowackiego. Wszystkie te fakty są doskonale znane i nie wymagają omówienia i interpretacji. Podobnie nie ma potrzeby analizowania historii formowania się polskiej granicy wschodniej oraz przebiegu wydarzeń militarnych i politycznych, po których ostatecznie wyznaczono ją na konferencji pokojowej w Rydze. Również zmagania o przynależność państwową Wilna doczekały się bogatej literatury przedmiotu.

Z punktu widzenia analizy polityczno-geograficznej jedna sprawa jest interesująca i wymaga rozpatrzenia. Chodzi mianowicie o konfrontację projektu Romana Dmowskiego z faktyczną sytuacja, jaka zaistniała po ostatecznym wyty-

23 Roman Dmowski zakładał, że kwestia ta zostanie rozwiązana w sposób kompromisowy w bezpośrednich rozmowach miedzy stroną polską a czechosłowacką. R. Dmowski, Polityka polska (1947), t. 2, s. 155

24 Powiat ten został przyznany Polsce przed plebiscytem. czeniu granic odrodzonej Rzeczypospolitej Polskiej i jej najbliższych sąsiadów. Okazało się, że zachodnie granice państwa polskiego (z Niemca$\mathrm{mi}$ ), południowe (z Czechosłowacją) i północne (z Prusami Wschodnimi i Wolnym Miastem Gdańskiem) nie zostały wyznaczone zgodnie z postulatami Dmowskiego. Polska w zasadzie musiała zaakceptować werdykt podjęty na konferencji pokojowej w Wersalu. Granica wschodnia została wytyczona na konferencji w Rydze i tu delegacja polska miała możliwość podejmowania samodzielnych decyzji wynikających z częściowej klęski przeciwnika.

W celu klarownego przedstawienia różnic między kartograficzną wizją Romana Dmowskiego a faktycznym układem granicznym uformowanym ostatecznie w $1921 \mathrm{r}$. i istniejącym bez zmian do 1938 r. załączono do tekstu współczesną mapę, na której autorzy wyrysowali propozycje terytorialne Dmowskiego na tle wersalsko-ryskich granic politycznych Polski. Różnice między oboma ujęciami świadczą pośrednio o skali niepowodzeń polskiej delegacji (mapa 4).

Ogólny zarys geopolityczny nie różni się w sposób znaczący, ale gdy przejść do kwestii szczegółowych, zaznaczają się duże rozbieżności, i to na wszystkich odcinkach granicznych. $\mathrm{Na}$ północnym wschodzie Polska zrzekła się centralnej Białorusi z Mińskiem, zaś na południowym wschodzie - małej części Podola za Zbruczem. Dla Romana Dmowskiego najważniejsza była granica zachodnia i tu też spotkało go wiele niepowodzeń, o których już wspominano. Dotyczyły one Prus Wschodnich, które przetrwały z wyjątkiem jednego powiatu działdowskiego. Polska uzyskała jedynie wąski korytarz prowadzący do morza ${ }^{25}$ oraz w zasadzie całą Wielkopolskę. Wysiłki dotyczące przyłączenia całego Górnego Śląska (w tym Opolszczyzny) nie przyniosły pozytywnego rezultatu. Do państwa polskiego udało się włączyć jedynie wschodnią część Górnego Śląska. Pod względem wielkości terytorialnej ubytki na pograniczu polsko-

\footnotetext{
25 Problematyka związana z powrotem części Pomorza do Polski została opisana w opracowaniu M. Wojciechowski, Powrót Pomorza do Polski 1918-1920, Warszawa-Poznań-Toruń 1981.
} 


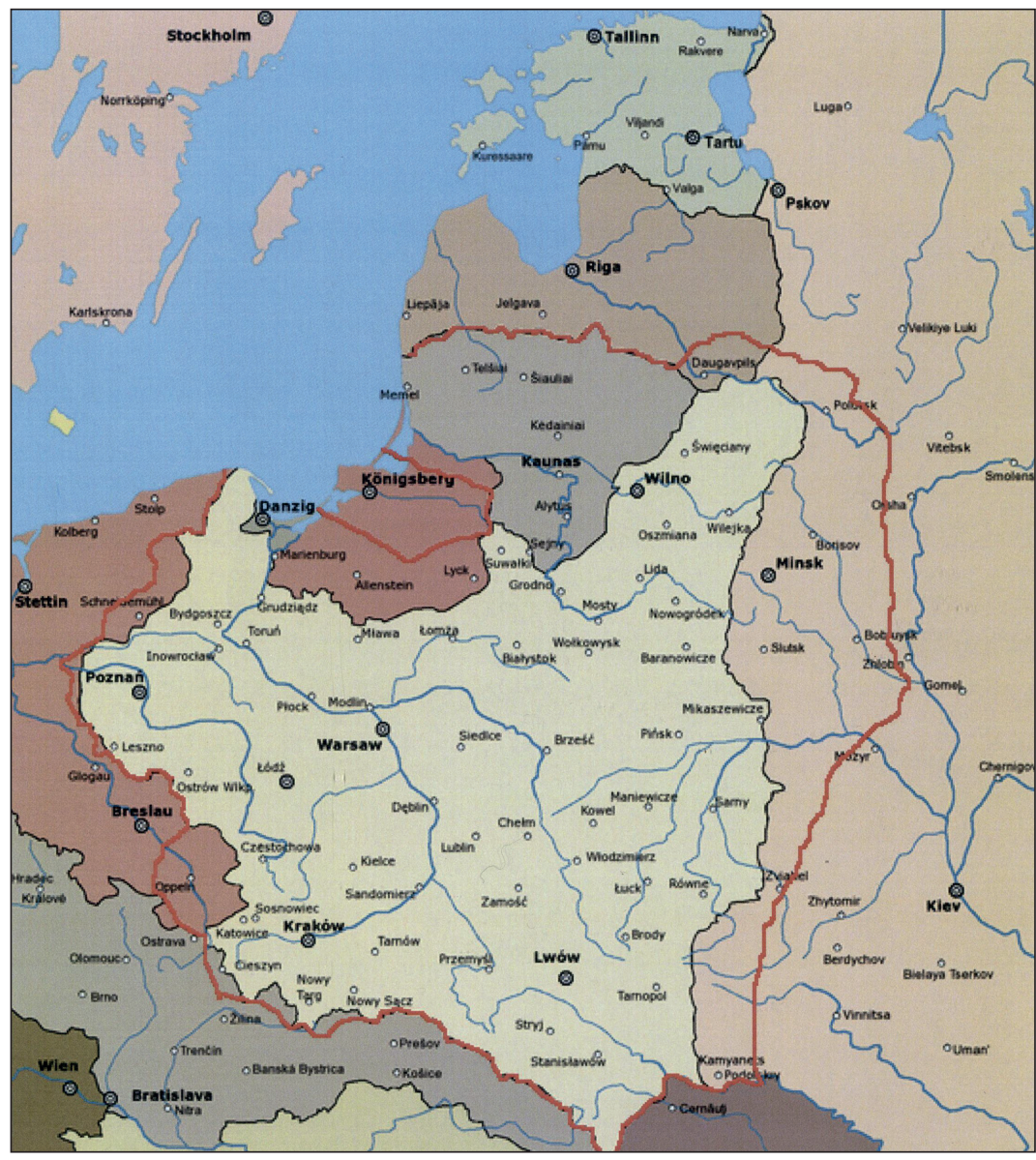

Mapa 4. Linia Dmowskiego i układ polityczny Europy po 1921 (http://pl.wikipedia.org/, dostęp: 1 lipca 2014)

-czechosłowackim były niezbyt duże. Niemniej jednak bolesna była utrata polskich obszarów etnicznych na Śląsku Cieszyńskim, zwłaszcza że były to tereny uprzemysłowione, $\mathrm{z}$ wieloma kopalniami węgla kamiennego i wielką hutą żelaza w Trzyńcu. Z wyjątkiem kilku gmin na Spiszu i Orawie większość tych dwóch historycznych prowincji znalazła się w granicach Czechosłowacji. Zgodnie z koncepcją Romana Dmowskiego i po licznych perturbacjach została ostatecznie wytyczona granica polsko-litewska, a Wilno znalazło się w granicach Polski.

$\mathrm{Na}$ podstawie oficjalnych dokumentów i załączonej ilustracji kartograficznej starano się w niniejszym tekście zaprezentować zarys polskiego programu terytorialnego, który został opracowany przez Komitet Narodowy Polski, a następnie przedstawiony przez delegację polską na konferencji pokojowej w Paryżu. Nie budzi wątpliwości fakt, że inicjatorem, kreatorem, a w końcu prezenterem dezyderatów polskich był jej przewodniczący Roman Dmowski. W trakcie obrad siłą swego przekazu potrafił przekonać wielkich tego świata o konieczności wskrzeszeniapaństwapolskiego.Skonstruowany przez niego program miał wysoką wartość merytoryczną i był właściwie uzasadniony, co zostało docenione przez mocarstwa zachodnie. Najważniejszym zamierzeniem programu było zjednoczenie ziem polskich będących częścią składową trzech państw zaborczych - Rosji, Niemiec i Austro-Węgier. To najważniejsze zadanie zostało zrealizowane i optymistyczne przewidywania Romana Dmowskiego spełniły się. 
Poprzez zjednoczenie ziem polskich nastąpić musiała odbudowa polskiej państwowości.

Dla zrealizowania tego celu delegacja polska wykorzystała wiele argumentów prawnych, historycznych, geopolitycznych, politycznych, etnicznych i społeczno-gospodarczych ${ }^{26}$. Były one na tyle silne, że wiele $\mathrm{z}$ nich przekonało nawet zagorzałych oponentów. Przy redagowaniu ostatecznego werdyktu konferencji w Wersalu nikt już nie kwestionowal, że istnieje konieczność odtworzenia suwerennego państwa polskiego w granicach gwarantujących jego egzystencję państwową. To najważniejsze zadanie, które na początku wojny wydawało się utopijne, zostało w pełni wykonane.

Kolejnym problemem wymagającym optymalnego rozwiązania była korzystna konfiguracja granic, gwarantująca funkcjonowanie państwa i jego trwałość. Najważniejszą sprawą determinującą przyszłość był nieograniczony dostęp do morza. Mimo że na początku konferencji pojawiały się liczne wątpliwości i kwestia ta nie była przesądzona, to przy ustalaniu ostatecznego werdyktu było już wiadomo, że dostęp do Bałtyku będzie zapewniony. Nie udało się odzyskać Gdańska, co było istotnym utrudnieniem, ale zostało ono pokonane poprzez budowę portu gdyńskiego ${ }^{27 .}$

W kwestiach związanych z przebiegiem granic obok sukcesów było też wiele porażek. Delegaci polscy starali się je zminimalizować, a za- sięg terytorialny Polski nie został ograniczony do niewielkiego obszaru etnicznego. W granicach Rzeczypospolitej znalazła się część Kresów Wschodnich ze Lwowem i Wilnem oraz obszerne pogranicze polsko-niemieckie będące kolebką państwowości polskiej. Tu niepowodzenia były największe, gdyż nie odzyskano wielu strategicznie i gospodarczo ważnych obszarów, na których mieszkało wielu Polaków. Przy okazji każdej z tych kontrowersyjnych spraw polscy delegaci z olbrzymim zaangażowaniem pracowali na to, aby decyzja wielkich mocarstw była dla Polski korzystna. Byli oni wymagającymi partnerami i wykorzystywali przychylne stanowisko delegacji francuskiej. Można założyć, że bez właściwego przygotowania merytorycznego, posiadania wyraźnie sprecyzowanego programu terytorialnego oraz aktywności w trakcie obrad wyniki końcowe byłyby znacznie skromniejsze.

Porządek wersalski trwał prawie dwadzieścia lat i dopiero zdemontowanie go przez hitlerowskie Niemcy i stalinowski ZSRR doprowadziło do nowej wojny, a po jej zakończeniu - do nowego podziału terytorialnego Europy i Polski. Decyzje wielkich mocarstw zapadły tym razem w Jałcie i Poczdamie. Konsekwencje traktatu wersalskiego były na tyle istotne, że w czasie drugiej wojny światowej mocarstwa zachodnie nie kwestionowały już potrzeby odbudowy państwa polskiego w ściśle określonych granicach politycznych.
26 Pełną dokumentację z konferencji pokojowej w Wersalu zebrano, uporządkowano i opublikowano: K. Kumaniecki, Odbudowa państwowości; Problem polsko-niemiecki w traktacie wersalskim, red. J. Pajewski, Poznań 1963; Sprawy polskie na konferencji pokojowej w Paryżu w 1919 r. Dokumenty i materiały, red. R. Bierzanek, J. Ku- kułka, Warszawa 1965-1967; Dokumenty z dziejów polskiej polityki zagranicznej 1918-1939, red. T. Jędruszczak, M. Nowak-Kiełbikowa, Warszawa 1989; Ekspertyzy i materiaty.

27 Decyzję 0 budowie portu w Gdyni rząd polski podjął jesienią 1920 r. 


\section{Bibliografia}

Batowski H., Zachód wobec granic Polski 19201940: niektóre fakty mniej znane, Łódź 1995.

Baumgart M., Wielka Brytania a odbudowa Polski 1914-1923, Szczecin 1990.

Dmowski R., Polityka polska i odbudowanie państwa, w: tenże, Wybór pism, t. 1, Poznań 2014, s. 141-754.

Dmowski R., Polityka polska i odbudowanie państwa, t. 1-2, Hanower 1947.

Dokumenty z dziejów polskiej polityki zagranicznej 1918-1939, red. T. Jędruszczak, M. Nowak-Kiełbikowa, Warszawa 1989.

Eberhardt P., Polska i jej granice. Z historii polskiej geografii politycznej, Lublin 2004.

Ekspertyzy i materiaty delegacji polskiej na konferencje wersalska 1919, red. M. Przyłuska-Brzostek, Warszawa 2009.

Kozicki S., Sprawa granic Polski na konferencji pokojowej w Paryż 1919 r., Warszawa 1921.

Kumaniecki K., Odbudowa państwowości polskiej. Najważniejsze dokumenty 1912-1924, Warszawa-Kraków 1924.

Leczyk M., Komitet Narodowy Polski a Ententa $i$ Stany Zjednoczone, Warszawa 1966.

Pajewski J., Wokót sprawy polskiej. Paryż-Lozanna-Londyn 1914-1918, Poznań 1970.

Piszczkowski T., Odbudowanie Polski 19141919, Londyn 1969.
Pobóg-Malinowski W., Najnowsza historia polityczna Polski, t. 2, słowo wstępne B. Świderski, Londyn 1953.

Powrót Polski na mapę Europy, red. C. Bloch, Z. Zieliński, Lublin 1995.

Problem polsko-niemiecki $w$ traktacie wersalskim, red. J. Pajewski, Poznań 1963.

Romer E., Geograficzno-statystyczny atlas Polski, Lwów-Warszawa 1921.

Romer E., Pamiętnik paryski (1918-1919), Kraków 1989.

Skirmunt K., Moje wspomnienia 1866-1945, red. E. Orlof, A. Pasternak, Rzeszów 1997.

Sprawy polskie na konferencji pokojowej $w$ Paryżu w 1919 r. Dokumenty i materiaty, red. R. Bierzanek, J. Kukułka, Warszawa 19651967.

Wapiński R., Komitet Narodowy Polski i jego wktad $w$ odbudowe niepodlegtości Polski (1917-1919), w: Powrót Polski na mapę Europy, red. C. Bloch, Z. Zieliński, Lublin 1995.

Wojciechowski M., Powrót Pomorza do Polski 1918-1920, Warszawa-Poznań-Toruń 1981.

Wroniak Z., Sprawa polskiej granicy zachodniej w latach 1918-1919, Poznań 1963.

Zamoyski J., Powrót na mapę Polski. Komitet Narodowy w Paryżu 1914-1919, Londyn 1984.

\section{The Territorial Program of the Polish National Committee and the Polish Government Delegation at the Peace Conference in Versailles}

\section{Summary}

The article presents the territorial program of Poland prepared in the years $1917 / 1919$ by the Polish National Committee. The latter was a political organization initially working in Lausanne and later in Paris. Its unquestionable leader and ideologist was Roman Dmowski. After the Polish National Committee initiated its activity, it prepared a project of the postulated future borders of the Polish state (map No. 1). It contained the Kingdom of Poland, Wielko- polska (Greater Poland), Gdańsk Pomerania, East Prussia, ethnical Lithuania with Vilnius, Austrian Galicia, Polesia, Grodno governorate and a small part of western Volhynia. The eastern border was marked along the German-Russian front in August 1917. The program of the border was in those political conditions unrealistic; however, it provided the basis to prepare an official standpoint of the Polish government delegation at the Peace Conference in 
Paris. In the meantime, the political relations underwent changes, which was caused by the defeat of the Central Powers and the revolution in Russia. The author of the territorial program of Poland was Dmowski himself and he presented it during the sessions of the victorious western powers in Vienna. The principal element of the program was a map which showed a cartographic presentation of Poland's territorial claims (map No. 2). The Polish standpoint was an object of controversy between the great powers. The Polish desiderata were supported by France and opposed by Great Britain. This was presented and commented upon. The final effect was the creation of an independent Polish state whose western borders were determined in the Treaty of Versailles. The later Polish-Bolshevik war finished with the Treaty of Riga (1921), which established the eastern borders of Poland. The further part of the present article provides a comparative analysis of the Polish postulates and the later actual political borders (map No. 3). Not all Polish postulates were fulfilled. Nevertheless, a sovereign Polish state was created with access to the sea, while the borders of the invaders (Germany, Russia and Austro-Hungary), which tore the Polish territories apart and which were established during the Congress of Vienna (1815), disappeared.

Słowa kluczowe: granice Polski, traktat wersalski, Roman Dmowski

Keywords: borders of Poland, Treaty of Versailles, Roman Dmowski

prof. dr hab. Piotr Eberhardt - pracownik Zakładu Przestrzennego Zagospodarowania w Instytucie Geografii i Przestrzennego Zagospodarowania Polskiej Akademii Nauk, przewodniczący Rady Naukowej Instytutu Geopolityki (e-mail: p.ebe@twarda.pan.pl) 